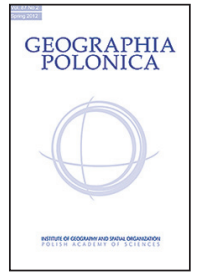

\title{
THE DIVERSITY OF SOILS OF THE UPPER FOREST LINE, TRANSITION, AND MOUNTAIN PINE ZONES IN THE BABIA GÓRA MASSIF
}

\author{
Paweł Nicia1 ${ }^{1}$ Paweł Zadrożny ${ }^{1}$ - Barbara Czajka² \\ ${ }^{1}$ Department of Soil Science and Soil Protection \\ University of Agriculture in Krakow \\ Mickiewicza 21, 31-120 Krakow: Poland \\ e-mail: rrnicia@cyf-kr.edu.pl•rrzadroz@cyf-kr.edu.pl \\ ${ }^{2}$ Faculty of Earth Science \\ University of Silesia in Katowice \\ Będzińska 60, 41-200 Sosnowiec: Poland \\ e-mail: barczajka@wp.pl
}

\begin{abstract}
The upper forest line transition zone up to the mountain pine zone on the southern slopes of Babia Góra, has diversified phytosociology and soils. The development and diversity of the upper forest soils are affected by morphogenetic processes, physiographic conditions, vegetation, and anthropogenic factors which in the past included sheep grazing. An analysis conducted on the morphological and chemical soil properties in the transects covering the upper forest line, transition, and mountain pine zone on the southern slopes of Babia Góra revealed considerable diversification characterising these soils within the individual altitude zones. A substantial changeability in the contents of the analysed components in the investigated soils is characteristic for mountain soils developed in the areas with great intensity of slope phenomena and processes.
\end{abstract}

\section{Key words}

Babia Góra Mt • soils • upper forest line

\section{Introduction}

On Babia Góra, like in the other parts of the Carpathians, the kind of bedrock, geomorphological processes, vegetation, climate or physiographic conditions are among the factors affecting development of soil cover (Kotarba 1990; Skiba 1995, 2006; Miechówka et al. 2004). There are also the anthropogenic factors to be considered, mainly associated with sheep farming (Zaleski 1996), which on this terrain was most intensive in the 18th and 19th centuries (Czajka et al. 2010). At that time, the highest situated tree stands were cut down, which led to the lowering of the upper forest line. Pasturing has since 
been discontinued on the Babia Góra slopes, and the gradual process of vegetation cover reconstruction has been taking place due to succession (Czajka et al. 2010). Because of very strong dependencies between the vegetation and soil of a given habitat (Skiba 1998; Miechówka et al. 2004, 2006), the process may influence the development of soil cover and diversification of properties within a soil profile of this region.

The investigations attempted to determine the effect of habitat changes on soil properties in the transition zone between the upper forest line and mountain pine zone on the southern slopes of Babia Góra.

\section{Materials and methods}

Five research polygons $-1,2,3,4$, and 5 were appointed to determine the soil properties of the upper forest (Fig.1). On each of the polygons, three soil pits were made that were located as follows:

- in plant communities of the upper mountain zone (PRG), where the acidophilus West-Carpathian upper mountain spruce (Plagiothecio-Piceetum) occurred,

- in the transition zone (SP) between the upper forest line and mountain pine shrubs,

- in the mountain pine zone under mountain pine (Pinusmogo) shrubs, under grassy vegetation and herb communities (PK).

Fifteen soil profiles were made, whose localisation was determined using the GPS technique (Tab.1).

During field work, soil morphological properties were determined and samples for laboratory analyses were taken from each of the identified genetic horizons. The following assessments were made in the samples:

- $\mathrm{pH}$ in $\mathrm{H}_{2} \mathrm{O}$ and $1 \mathrm{~mol} \cdot \mathrm{dm}^{-3} \mathrm{KCl}$ solution by the electrometric method using $\mathrm{pH}$-meter with a universal electrode calibrated in buffer solutions (Tan 1996),

- hydrolytic acidity (Hh) by Kappen's method following extraction with $1 \mathrm{~mol} \cdot \mathrm{dm}^{-3}$ $\mathrm{CH}_{3} \mathrm{COOHNa}$ (Lityński et al. 1976),

- exchangeable acidity using Sokołow's method, after extraction with $1 \mathrm{~mol} \cdot \mathrm{dm}^{-3} \mathrm{KCl}$, in whose extract exchangeable $\mathrm{H}^{+}$was determined after precipitation of $\mathrm{Al}^{3+}$ ions with $2.3 \mathrm{~mol} \cdot \mathrm{dm}^{-3} \mathrm{NaF}$ (Lityński et al. 1976),

- base exchange capacity (S) through determining individual cations $\left(\mathrm{Ca}^{+2}, \mathrm{Mg}^{+2}, \mathrm{~K}^{+}\right.$, $\mathrm{Na}^{+}$) after their extraction with $1 \mathrm{~mol} \cdot \mathrm{dm}^{-3}$ $\mathrm{CH}_{3} \mathrm{COONH}_{4}$ (Lityński et al. 1976) using the ICP-AES technique,

- organic carbon content (C org.), total nitrogen ( $\mathrm{N}$ og.) and total sulphur (S og.) by means of the thermal method using an LECO C-NS 2000 analyser,

- content of available phosphorus (P) and potassium (K) extracted using the Enger-Riehm method (Lityński et al. 1976 ) by means of the ICP-AES method.

On the basis of the obtained results, the following were computed:

- potential cation exchange capacity (PCEC): $\mathrm{PCEC}=\mathrm{Hh}+\mathrm{S}$

- sorption complex saturation with base cations (V):

$$
V=\frac{S}{\text { PCEC }} \cdot 100
$$

\section{Results and discussion}

Soils of the southern part of the Babia Góra massif developed from the Magura sandstones on slopes having an average gradient of $25^{\circ}$. Despite such a considerable slope gradient, all analysed soils were characterised by well-developed, mostly organic-accumulative horizons. These horizons formed as a result of the accumulation of organic matter originating from the decomposed vegetation which covered the horizons. An apparent zonality of soil location occurs in the Babia Góra area (Adamczyk \& Baran 1963; Adamczyk 1983; Miechówka et al. 2004, 2006), which causes a diversity within the soil profile, especially as far as the thickness of accumulative horizons is concerned. Accumulative horizons having the greatest thickness characterised the soils covering the upper mountain zone, under upper mountain forest, where the average thickness was $10.4 \mathrm{~cm}$. In soils of the transition zone between the upper mountain 


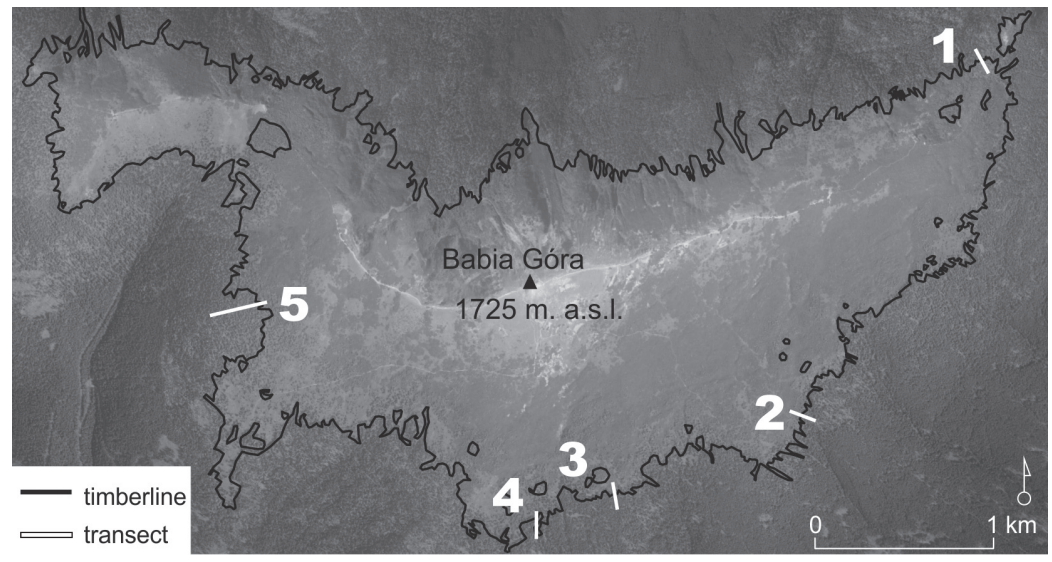

Figure 1. Location of research transects

Table 1. Typological classification and localisation of the analysed soils

\begin{tabular}{|c|c|c|c|}
\hline Profile & $\begin{array}{c}\text { Soil type and sub-type } \\
\text { (Marcinek \& Komisarek 2011) }\end{array}$ & Localisation and altitude & $\begin{array}{c}\text { Vegetation } \\
\text { (Matuszkiewicz 2005) }\end{array}$ \\
\hline 1PRG & Cambic Skeletic Leptosols & $\begin{array}{l}49 \circ 35^{\prime} 00,8^{\prime \prime} \mathrm{N}, 19 \circ 33^{\prime} 41,5^{\prime \prime} \mathrm{E} \\
1367 \text { m n.p.m. }\end{array}$ & $\begin{array}{l}\text { acidophilous West Carpathian moun- } \\
\text { tain spruce (Plagiothecio-Piceetum) }\end{array}$ \\
\hline $1 S P$ & Cambic Skeletic Leptosols & $\begin{array}{l}49 \circ 35^{\prime} 00,4^{\prime \prime} \mathrm{N}, 19 \circ 33^{\prime} 41,4^{\prime \prime} \mathrm{E} \\
1370 \text { m n.p.m. }\end{array}$ & $\begin{array}{l}\text { transition zone between closed forest } \\
\text { and mountain pine shrubs }\end{array}$ \\
\hline $1 \mathrm{PK}$ & Cambic Skeletic Leptosols & $\begin{array}{l}49 \circ 35^{\prime} 00,1^{\prime \prime} \mathrm{N}, 19 \circ 33^{\prime} 42,5^{\prime \prime} \mathrm{E} \\
1380 \text { m n.p.m. }\end{array}$ & $\begin{array}{l}\text { mountain pine shrubs } \\
\text { (Pinusmugo) }\end{array}$ \\
\hline $2 P R G$ & Dystric Skeletic Leptosols & $\begin{array}{l}49 \circ 34^{\prime} 01,8^{\prime \prime} \mathrm{N}, 19 \circ 32^{\prime} 55,9^{\prime \prime} \mathrm{E} \\
1335 \text { m n.p.m. }\end{array}$ & $\begin{array}{l}\text { high mountain spruce } \\
\text { (Plagiothecio-Piceetum) }\end{array}$ \\
\hline $2 S P$ & Cambic Skeletic Leptosols & $\begin{array}{l}49 \circ 34^{\prime} 02,0^{\prime \prime} \mathrm{N}, 19 \circ 32^{\prime} 55,6^{\prime \prime} \mathrm{E} \\
1344 \text { m n.p.m. }\end{array}$ & $\begin{array}{l}\text { transition zone between closed forest } \\
\text { and mountain pine shrubs }\end{array}$ \\
\hline $2 \mathrm{PK}$ & Cambic Skeletic Leptosols & $\begin{array}{l}49 \circ 34^{\prime} 02,6^{\prime \prime} \mathrm{N}, 19 \circ 32^{\prime} 55,9^{\prime \prime} \mathrm{E} \\
1365 \text { m n.p.m. }\end{array}$ & $\begin{array}{l}\text { mountain pine shrubs } \\
\text { (Pinusmugo) }\end{array}$ \\
\hline $3 P R G$ & Cambic Skeletic Leptosols & $\begin{array}{l}49 \circ 33^{\prime} 48,1^{\prime \prime} \mathrm{N}, 19 \circ 32^{\prime} 06,8^{\prime \prime} \mathrm{E} \\
1384 \text { mn.p.m. }\end{array}$ & high mountain spruce \\
\hline $3 S P$ & Dystric Skeletic Leptosols & $\begin{array}{l}49 \circ 33^{\prime} 49,0^{\prime \prime} \mathrm{N}, 19 \circ 32^{\prime} 06,0^{\prime \prime} \mathrm{E} \\
1393 \text { m n.p.m. }\end{array}$ & $\begin{array}{l}\text { transition zone between closed forest } \\
\text { and mountain pine shrubs }\end{array}$ \\
\hline $3 P K$ & Hyper Skeletic Leptosols & $\begin{array}{l}49 \circ 33^{\prime} 48,3^{\prime \prime} \mathrm{N}, 19 \circ 32^{\prime} 06,4^{\prime \prime} \mathrm{E} \\
1411 \text { m n.p.m. }\end{array}$ & $\begin{array}{l}\text { mountain pine shrubs } \\
\text { (Pinusmugo) }\end{array}$ \\
\hline $4 P R G$ & Dystric Skeletic Leptosols & $\begin{array}{l}49 \circ 33^{\prime} 40,9^{\prime \prime} \mathrm{N}, 19 \circ 31^{\prime} 49,8^{\prime \prime} \mathrm{E} \\
1345 \text { m n.p.m. }\end{array}$ & high mountain spruce \\
\hline $4 S P$ & Cambic Skeletic Leptosols & $\begin{array}{l}49 \circ 33^{\prime} 42,2^{\prime \prime} \mathrm{N}, 19 \circ 31^{\prime} 48,8^{\prime \prime} \mathrm{E} \\
1366 \text { m n.p.m. }\end{array}$ & $\begin{array}{l}\text { transition zone between closed forest } \\
\text { and mountain pine shrubs }\end{array}$ \\
\hline $4 \mathrm{PK}$ & Cambic Skeletic Leptosols & $\begin{array}{l}49 \circ 33^{\prime} 45,5^{\prime \prime} \mathrm{N}, 19 \circ 31^{\prime} 48,4^{\prime \prime} \mathrm{E} \\
1391 \text { m n.p.m. }\end{array}$ & $\begin{array}{l}\text { mountain pine shrubs } \\
\text { (Pinusmugo) }\end{array}$ \\
\hline $5 P R G$ & Dystric Skeletic Leptosols & $\begin{array}{l}49 \circ 34^{\prime} 21,1^{\prime \prime} \mathrm{N}, 19 \circ 30^{\prime} 27,7^{\prime \prime} \mathrm{E} \\
1420 \text { m n.p.m. }\end{array}$ & high mountain spruce \\
\hline $5 S P$ & Cambic Skeletic Leptosols & $\begin{array}{l}49 \circ 34^{\prime} 20,6^{\prime \prime} \mathrm{N}, 19 \circ 30^{\prime} 29,8^{\prime \prime} \mathrm{E} \\
1440 \text { m n.p.m. }\end{array}$ & $\begin{array}{l}\text { transition zone between closed forest } \\
\text { and mountain pine shrubs }\end{array}$ \\
\hline $5 \mathrm{PK}$ & Skeletic Leptosol & $\begin{array}{l}49 \circ 34^{\prime} 21,1^{\prime \prime} \mathrm{N}, 19 \circ 30^{\prime} 27,7^{\prime \prime} \mathrm{E} \\
1448 \text { m n.p.m. }\end{array}$ & $\begin{array}{l}\text { mountain pine shrubs } \\
\text { (Pinusmugo) }\end{array}$ \\
\hline
\end{tabular}


Table 2. Chemical properties of analysed soils (median value/variation coefficient)

\begin{tabular}{|c|c|c|c|c|c|c|c|c|c|c|c|}
\hline \multirow{2}{*}{$\begin{array}{c}\text { Altitude } \\
\text { zone }\end{array}$} & Corg. & Nog. & Sog. & K & $\mathrm{P}$ & \multicolumn{2}{|c|}{$\mathrm{pH}$} & S & $\mathrm{Hh}$ & PWK & $\mathrm{V}$ \\
\hline & \multicolumn{3}{|c|}{$\mathrm{g} \cdot \mathrm{kg}^{-1}$} & \multicolumn{2}{|c|}{$\mathrm{mg} \cdot \mathrm{kg}^{-1}$} & $\mathrm{H}_{2} \mathrm{O}$ & $\mathrm{KCl}$ & \multicolumn{3}{|c|}{$\mathrm{mmol}(+) \cdot \mathrm{kg}^{-1}$} & $\%$ \\
\hline \multicolumn{12}{|c|}{ Accumulative horizons } \\
\hline PRG & $283.6 / 0.7$ & $14.9 / 0.6$ & $1.43 / 0.6$ & $216.4 / 0.9$ & $145.2 / 0.7$ & $3.6 / 0.1$ & $2.76 / 0.1$ & $28.4 / 1.2$ & $735.0 / 0.6$ & $887.3 / 0.6$ & $3.6 / 1.0$ \\
\hline$S P$ & $121.6 / 0.9$ & $6.1 / 0.8$ & $0.8 / 0.7$ & $85.6 / 1.0$ & $101.7 / 0.8$ & $3.8 / 0.1$ & $2.9 / 0.12$ & $7.3 / 1.3$ & $420 / 0.6$ & $426.9 / 0.7$ & $1.6 / 1.0$ \\
\hline PK & $123.2 / 0.8$ & $7.7 / 0.7$ & $1.0 / 0.6$ & $143.7 / 0.9$ & $131.8 / 0.8$ & $3.8 / 0.2$ & $3.1 / 0.3$ & $78.3 / 0.7$ & $302.9 / 0.8$ & $323.9 / 0.8$ & $8.8 / 1.1$ \\
\hline \multicolumn{12}{|c|}{ Enrichment horizons } \\
\hline PRG & $58.0 / 0.6$ & $3.0 / 0.6$ & $0.4 / 0.6$ & $60.6 / 0.5$ & $54.8 / 0.2$ & $4.0 / 0.1$ & $3.2 / 0.1$ & $2.9 / 0.5$ & $260.6 / 0.5$ & $263.5 / 0.4$ & $1.1 / 1.0$ \\
\hline$S P^{\star}$ & 58.0 & 3.5 & 0.5 & 52.3 & 30.6 & 3.5 & 2.9 & 2.9 & 260.6 & 263.6 & 1.1 \\
\hline $\mathrm{PK}^{*}$ & 30.4 & 2.9 & 0.4 & 92.9 & 59.1 & 4.2 & 3.6 & 2.4 & 137.8 & 140.2 & 1.7 \\
\hline \multicolumn{12}{|c|}{ Bedrock levels } \\
\hline PRG & $41.5 / 0.5$ & $2.2 / 0.4$ & $0.3 / 0.4$ & $42.3 / 0.4$ & $37.2 / 0.1$ & $4.0 / 0.1$ & $3.3 / 0.1$ & $1.9 / 0.5$ & 204.4/0.3 & $206.4 / 0.3$ & $0.8 / 0.4$ \\
\hline SP & $24.3 / 0.4$ & $1.8 / 0.4$ & $0.2 / 0.6$ & $63.8 / 0.5$ & $34.4 / 0.3$ & $4.2 / 0.1$ & $3.7 / 0.1$ & $1.2 / 0.4$ & $129.9 / 0.3$ & $131.1 / 0.3$ & $0.9 / 0.2$ \\
\hline PK & $15.2 / 0.6$ & $0.5 / 1.1$ & $0.1 / 0.8$ & $33.3 / 0.4$ & $31.2 / 0.6$ & $4.7 / 0.1$ & $4.0 / 0.1$ & $1.6 / 0.6$ & $82.5 / 0.3$ & $84.1 / 0.4$ & $1.9 / 0.3$ \\
\hline
\end{tabular}


zone and the mountain pine zone, the thickness of accumulative horizons was similar, i.e. $10 \mathrm{~cm}$. The soils located in the mountain pine zone were characterised by the lowest average thickness of accumulative horizons $-7.8 \mathrm{~cm}$.

On the basis of morphological features and the results of occurring pedogenic processes, the soils in the transects were classified to Hyperskeletic Leptosols (1 profile) and Skeletic Leptosols (1), Cambic Skeletic Leptosols (9 profiles) and Dystric Skeletic Leptosols (4 profiles) (Tab. 1) (Marcinek \& Komisarek 2011).

Surface horizons of soils in the upper mountain zone under the acidophilic West Carpathian high mountain spruce (PlagiothecioPicetum) were characterised by higher contents of organic carbon, total nitrogen and sulphur, available phosphorus, and potassium, in comparison with analogous horizons in the soils of the transition zone and those formed under mountain pine shrubs. The lowest contents of these components were assessed in accumulative soil horizons of the transition zone (Tab. 2).

The concentrations of organic carbon, total nitrogen, sulphur, available phosphorus, and potassium in the enrichment horizons of the upper mountain zone soils were greatly diversified. In the soils of the other analysed altitude zones these horizons only formed in single profiles (Tab. 2).

Bedrock horizons in soils of the upper mountain zone were apparently more enriched in organic carbon, total nitrogen, sulphur, and available phosphorus in comparison with the analogous horizons of the transition zone and those developed under mountain pine. Unlike the accumulative horizons, the lowest concentrations of these elements in bedrock horizons were determined in the soils formed under mountain pine (Tab. 2).

The contents of the analysed elements assessed in the soils are comparable with the results obtained by other authors who conducted soil research on Babia Góra (Borowiec 1961; Adamczyk \& Baran 1963; Adamczyk 1983; Miechówka et al. 1998, 2006; Niemyska-Łukaszuk et al. 1998a,b; Niemyska-Łukaszuk;
Kowalczyk \& Miechówka 2001; Zadrożny \& Miechówka 2008).

In all the soils, the contents of organic carbon, total nitrogen and sulphur, available phosphorus and potassium, decreased with their profile depth. The lowest concentrations of these elements were assessed in bedrock horizons (Tab. 2). Such an arrangement of the profile distribution of the analysed macro-elements resulted from a visible diversification between the surface accumulative horizons (with high contents of organic matter) and underlying sub-surface horizons. These results are seen in the high values of computed correlation coefficients $r^{2}$ between organic carbon content and concentrations of the other determined elements ( $\mathrm{C}$ org. and $\mathrm{N}$ org. $r^{2}+0.8344 ; C$ org and $S$ org, $r^{2}=0.7575$; $C$ org and $K r^{2}=0.7000$ and $P r^{2}=0.6224$ ).

In all the soils, the $\mathrm{pH}$ values assessed in the $\mathrm{KCl}$ solution did not exceed 4.5, which according to the division accepted in Poland (Gliński 1995), allows them to be classified as very strongly acid soils. The low $\mathrm{pH}$ in the soils results from their genesis from the bedrock which is a carbonateless Magura sandstone, and the characteristics of accumulated organic matter under plant communities occurring on them (Kowalczyk \& Miechówka 2001; Miechówka et. al. 2006; Zadrożny \& Miechówka 2008).

On the basis of the assessed parameters determining sorption abilities, it was found that they characterise soils from the upper forest line (Tab. 2). In these soils, both in their accumulative horizons and bedrock assessed values of hydrolytic acidity and base exchange capacity, the sorption capacity and sorption complex saturation with exchangeable cations were higher than for the analogous soils of the transition zone and the mountain pine zone (Tab. 2).

In comparison with the subsurface horizons, high values of hydrolytic acidity assessed in the surface horizons of the analysed soils (irrespective of their location) resulted from the presence of acidifying compounds formed during biomass decomposition, with a considerable share of needles forming 
the undergrowth (Kowalczyk \& Miechówka 2001).

In all the soils, irrespective of the zone, the sorption complex of surface horizons was more saturated with base cations than in the subsurface horizons. The high content of base cations in the subsurface horizon of soils developed on carbonateless substratum, may be evidence of their enrichment with metal dusts and other alkaline elements deposited in the upper parts of the Babia Góra massif (Grodzińska et al. 1990; Niemyska-Łukaszuk 1992; NiemyskaŁukaszuk et al. 1998b).

A characteristic feature of the analysed transects was the considerable changeability of the transects' chemical properties, both within individual profiles and individual altitude zones, favoured by the characteristic geological structure of the Babia Góra Mt (Alexandrowicz 2004), which to a considerable extent contributes to the development of a mosaic, greatly diversified soil cover within one soil profile. It can be seen, that soils whose properties are affected by diversified pedogenic processes - podsolization and browning, developed in a transect several dozen meters long, running from the upper forest line through the transition zone to the mountain pine zone.

\section{References}

AdAmCZYK B., 1983. Charakterystyka gleb Babiogórskiego Parku Narodowego [in:] K. Zabierowski (ed.), Park Narodowy na Babiej Górze, Przyroda i człowiek. Studia Naturae, B, 29, Warszawa-Kraków: Zakład Ochrony Przyrody i Zasobów Naturalnych PAN, pp. 95-120.

Adamczyk B., Baran S., 1963. Gleby Babiej Góry [in:] Szafer W. (ed.), Babiogórski Park Narodowy, Kraków: Zakład Ochrony Przyrody PAN, pp. 89-109.

AleXandrowicz S.W., 2004. Zarys budowy geologicznej Babiej Góry [in:] B.W. Wołoszyn, A. Jaworski, J. Szwagrzyk (eds.), Babiogórski Park Narodowy: Monografia przyrodnicza.

\section{Conclusions}

1. Soils of the analysed transects in the individual zones (upper forest line, transition, and mountain pine zone) differed by morphological and chemical properties and typological affiliation.

2. Differences occurring in soils from individual altitude zones are most probably the effect of slope processes occurring on these terrains and diversification of vegetation covering them, irrespective of their former pasturing use.

3. Diversification of soil properties within the profiles was greatly determined by the quantity and profile distribution of organic matter.

\section{Acknowledgements}

The work described here forms part of research project NN 306070640 of the Polish National Science Centre, entitled Natural and anthropogenic conditioning of the occurrence of the timberline on Babia Góra Mountain, and its dynamics over the last 200 years.

\section{Editors' note:}

Unless otherwise stated, the sources of tables and figures are the authors' on the basis of their own research.

Kraków: Wydawnictwo i Drukarnia Towarzystwa Słowaków w Polsce, pp. 87-107.

BOROWIEC S., 1961. Charakterystyka gleb bielicowych i brunatnych kwaśnych w ważniejszych zespołach Babiogórskiego Parku Narodowego. Sylwan, vol. 105, no. 3, pp. 1-12.

Czajka B., Kaczka R., Guzik M., 2010. Dendrochronologiczny zapis zmian górnej granicy lasu [in:] Z. Mirek (ed.), Nauka a zarzqdzanie obszarem Tatr i ich otoczeniem. Volume 2: Człowiek i środowisko. Kraków: Tatrzański Park Narodowy, pp. 53-57.

GLIŃSKI J., 1995. Chemiczne i fizykochemiczne właściwości gleb [in:] B. Dobrzański, S. Zawadzki (eds.), Gleboznawstwo, Warszawa: Państwowe Wydawnictwo Rolnicze i Leśne, pp. 157-209. 
Grodzińska K., Szarek G., Godzik B., 1990. Heavy metal deposition in Polish National Parks changes during ten years. Water, Air and Soil Pollution, vol. 49, no. 3-4, pp. 409-419.

KotARBA A., 1990. Postęp metodyczny w badaniach wspótczesnych procesów morfogenetycznych [in:] A. Kotarba (ed.), Dokumentacja Geograficzna, współczesne procesy morfogenetyczne w Polsce, wybrane zagadnienia, vol. 1, pp. 7-13.

Kowalczyk E., MieChówKa A., 2001. Klasyfikacja kwaśnych gleb Babiogórskiego Parku Narodowego na podstawie profilowego rozmieszczenia różnych form żelaza. Roczniki Gleboznawcze, vol. 52, supl., pp. 127-133.

LitYŃSKI T., JuRKOWSKA H., GORLACH E., 1976. Analiza chemiczno-rolnicza. Warszawa: Państwowe Wydawnictwo Naukowe.

Marcinek J., KomisareK J., 2011. Systematyka gleb Polski. Roczniki Gleboznawcze, vol. 62, no. 3, Warszawa: Wydawnictwo Wieś Jutra, pp. 1-193.

Matuszkiewicz. W., 2001. Przewodnik do oznaczania zbiorowisk roślinnych. Warszawa: Państwowe Wydawnictwo Naukowe.

Miechówka A., Niemyska-Łukaszuk J., Nicia P., KowALCZYK E., 1998. Charakterystyka gleb pod zbiorowiskami Piceetum tatricum athyrietosum alpestris i Dentario glandulosae-Fagetum athyrietosum alpestris w Babiogórskim Parku Narodowym. Zeszyty Problemowe Postępów Nauk Rolniczych, 464, pp. 65-73.

Miechówka A., Niemyska-Łukaszuk J., Zaleski T., MaZurek R., 2004. Gleby Babiogórskiego Parku Narodowego [in:] B.W. Wołoszyn, A. Jaworski, J. Szwagrzyk (eds.), Babiogórski Park Narodowy: Monografia Przyrodnicza, Kraków: Wydawnictwo i Drukarnia Towarzystwa Słowaków w Polsce, pp. 197-211.

Miechówka A., Zadrożny P., Kowalczyk E., 2006. Podzol soils of different climatic and vegetattion belts of the Babiogórski National Park. Polish Journal of Soil Science, vol. 39, no. 1, pp. 73-79.
NiemySKA-ŁUKASZUK J., 1992. Skład frakcyjny próchnicy i zawartość metali ciężkich w górnoreglowych bielicach boru świerkowego Babiej Góry. Acta Agraria et Silvestria. Series Silvestris, 30, pp. 53-61.

Niemyska-Łukaszuk J., Miechówka A., Mazurek R., 1998a. Gleby Babiogórskiego Parku Narodowego [in:] A. Łajczak (ed.), Operat ochrony przyrody nieożywionej i gleb Babiogórskiego Parku Narodowego. Projekt planu ochrony BgPN. Zawoja: Dyrekcja BgPN [typescript].

Niemyska-Łukaszuk J., MiechówKa A., Zadrożny P., Mazurek R., 1998b. Metale ciężkie (Cd, Cr, Cu, $\mathrm{Mn}, \mathrm{Ni}, \mathrm{Pb}, \mathrm{Zn})$ w wybranych glebach Babiogórskiego Parku Narodowego. Zeszyty Problemowe Postępów Nauk Rolniczych, 464, pp. 311-320.

SkIBA S., 1995. Pokrywa glebowa [in:] J. Warszyńska (ed.), Karpaty Polskie, Kraków: Wydawnictwo Uniwersytetu Jagiellońskiego, pp. 69-76.

SKIBA S., 1998. Gleby górskie w systematyce gleb Polski. Zeszyty Problemowe Postępów Nauk Rolniczych, 464, pp. 26-35.

SkIBA S., 2006. Pokrywa glebowa strefy wysokogórskiej Karpat i jej zagrożenia. Roczniki Bieszczadzkie, 14, pp. 201-214.

TAN K. H., 1996. Soil sampling, preparation, and analysis. New York: Marcel Dekker.

Zadrożny P., MieChÓWKa A., 2008. Bielicowanie jako czynnik warunkujacy rozmieszczenie siarki w profile glebowym. Roczniki Gleboznawcze, vol. 59, no. 3-4, pp. 297-301.

ZALESKI T., 1996. Wpływ pasterskiego użytkowania na właściwości fizykochemiczne gleb polan Wyżnia Kira Miętusia i Zahradziska [in:] Z. Krzan (ed.), Przyroda Tatrzańskiego Parku Narodowego a człowiek. Stan i perspektywy badań tatrzańskich. Materiały I Ogólnopolskiej Konferencji Przyroda Tatrzańskiego Parku Narodowego a Człowiek. Stan i perspektywy badań tatrzańskich, Zakopane, 6-9 października 1995, Kraków-Zakopane: Polskie Towarzystwo Przyjaciół Nauk o Ziemi, Tatrzański Park Narodowy, pp. 90-93. 
http://rcin.org.pl 